\title{
FINANCIAL EXPENSES OF EU STRUCTURAL FUNDS IN RURAL AREAS IN POLAND
}

\author{
Maciej Stawicki ${ }^{1}, \mathrm{PhD}$ \\ ${ }^{1}$ Warsaw University of Life Sciences (WULS-SGGW)
}

\begin{abstract}
The main aim of the paper is to compare and assess the structure and value of implemented projects Co-financed by EU funds in perspective 2007-2013 in rural areas in comparison to the urban ones. The objectives of the study were to classify investment priorities assigned to each project into smaller number of homogenous groups and to identify the share of EU funded projects in the different types of areas. Desk research, review of literature and databases, statistical and descriptive methods were used. The material used was database of projects implemented in the period 2007-2016 co-financed by EU structural funds in the programming period 2007-2013 as of June 2018. Polish rural areas have had the highest share of funds (above $10 \%$ ) allocated on construction of transport infrastructure, developing energy infrastructure, social infrastructure; and projects enhancing nature, tourism and cultural development. The proportions between the allocation in urban and rural areas were uneven - in most cases much more funds were spent in the cities and towns, which is clearly connected with the polarization - diffusion model of Polish regional policy.
\end{abstract}

Key words: EU structural funds, rural areas, effects, expenses, investment priorities, Poland.

JEL code: $018, \mathrm{R} 42$.

\section{Introduction}

One of the European Union's aims is equalizing differences in the level of development of the Member States in the field of social, spatial and economic development. European funds are the basic instruments for implementing the European Union's regional policy (Pawlicki, 2014). Poland is one of the largest beneficiaries of EU funds, as in the period 2014-2020, the EU allocated to Poland 82.5 billion EUR.

As there are few studies on the use of EU funds in rural areas (Schrader, 1994; Zawisza \& Pachut, 2015; Pondel, 2017) or the studies concern mostly on the development and impact on agriculture (Kowalczyk, 2007; Satola, 2009), the author decided to analyse the differences in the EU funds absorption and their financial expenses and effects in rural and urban areas. The objectives of the study were to classify investment priorities assigned to each project into smaller number of homogenous groups and to identify and assess the structure and value of implemented projects cofinanced by EU funds in perspective 2007-2013 in rural areas in comparison to the urban ones. As a background, description of EU funds and strategic goals and the system of implementation of cohesion policy in Poland was shown.

Desk research (review of literature and databases, ordering, classification of projects), statistical methods (calculations, relative and absolute indicators), field observations and descriptive methods were used, the data were presented using tables and graphs elaborated with Excel software.

The material used was database of projects implemented in the period 2007-2016 supported by all co-financed by EU structural funds domestic programs as of June 2018 downloaded from the national website concerning EU funding in Poland (funduszeeuropejskie.2007-2013.gov.pl, 2018). Two programs were excluded from the study: Human Capital Program and Programs of European Territorial Cooperation because the databases made it impossible to identify the share of funds spent in rural and urban areas. The data were published by Ministry of Economic Development of the Republic Poland (MED). During the analysis of Polish database, the author sometimes came across errors in project classification, so some of the results should be treated with caution. The project types were analysed and classified into the following groups according to the given in database 
investment priorities: Innovations and entrepreneurship, ICT, Transport, Energy, Environment protection, Nature, tourism and culture, Social infrastructure, Other.

\section{EU funds and their implementation in Poland in the period 2007-2013}

Structural funds are an instrument of European Union's regional and cohesion policy used to reduce regional differences (Bachtler J., Turok I., 2013). Among many financial instruments, the EU has the following five main funds supporting the economic development of countries in line with the Europe 2020 strategy and its objectives. The first of these funds is the European Regional Development Fund (ERDF), which aims to reduce disparities in the levels of development of regions in the European Union and is intended to strengthen economic, territorial and social cohesion. Funds from this fund are earmarked, among others, for supporting infrastructure and production investments as well as support for small and medium-sized enterprises. The second fund is the European Social Fund (ESF), whose main goal is to combat unemployment among member countries. Funds from this fund increase employment and education opportunities. Support for social groups and regions is also co-financed, and is especially dedicated to young people entering the labour market. Another fund is the Cohesion Fund, whose funds are earmarked for member states whose gross national income per capita is less than $90 \%$ of the EU average. The purpose of this fund is to reduce economic and social disparities as well as to promote sustainable development through investments in transport infrastructure and environmental protection. The fourth fund is the European Agricultural Fund for Rural Development, whose task is to support transformations in the structures of agriculture as well as to support development in rural areas. The last fund is the European Maritime and Fisheries Fund, supporting the restructuring of fisheries in the member states. In addition to the structural funds and the Cohesion Fund described above, in the programming period 2007-2013 there were also Community Initiatives: JASPERS providing technical support during the preparation of significant infrastructure projects, JESSICA supporting sustainable urban development and JEREMIE aiming at support for the activities of small and medium-sized enterprises. In this paper, support by CF, ERDF and ESF will be assessed.

The assistance discussed in the article in the period 2007 - 2013 was intended to achieve the objectives of the Lisbon Strategy and regional policy strategies, which were designed to decrease differences in the levels of regional development. The strategy of socio-economic development of Poland revealed itself in such challenges as: building a competitive economy, increasing investments in human capital, improving road infrastructure, protecting the natural environment, or creating conditions for appropriate economic growth. In Poland, the National Strategy for Cohesion (NSS) (official name: National Strategic Reference Framework, NSRF) was the strategic document defining the priorities and areas of use and the system of implementing EU funds. It set out the rules for spending the European Regional Development Fund (ERDF), the European Social Fund (ESF) and the Cohesion Fund under the Community budget for 2007-13.

The strategic goal of NSS was to create conditions for the growth of competitiveness of the Polish economy based on knowledge and entrepreneurship, ensuring employment growth and increasing the level of social, economic and spatial cohesion. The strategic goals were to be achieved through the implementation of horizontal specific objectives (NSRO, 2007):

- Improving the quality of public institutions' functioning and developing partnership mechanisms,

- Improving the quality of human capital and increasing social cohesion, 
- Construction and modernization of technical and social infrastructure essential for the growth of Poland's competitiveness,

- Increasing the competitiveness and innovativeness of enterprises, in particular the manufacturing sector with high added value and the development of the services sector,

- Increasing competitiveness of Polish regions and counteracting their social, economic and spatial marginalization,

- Equalizing development opportunities and supporting structural changes in rural areas.

The investment priorities set in Poland and the share of funds for were similar to other countries in the region. For example, in all V4+4 countries the biggest part of the allocation was invested in transportation, energy and environmental projects (The Impact of Cohesion Policy..., 2017). Investments in innovations, companies, R\&D potential was a priority in the Czech Republic and Slovenia, while in Poland transport projects have had the highest share.

In addition to legal, fiscal and institutional activities, NSS objectives were implemented through programs (so-called operational programs) managed by the Ministry of Regional Development, regional programs (so-called regional operational programs) managed by the Management Boards of individual Voivodships and projects co-financed by the structural instruments, i.e .:

- Infrastructure and Environment Program - co-financed by ERDF and CF

- Innovative Economy Program - ERDF,

- Human Capital Program - ESF,

- 16 regional programs - ERDF,

- Program Development of Eastern Poland - ERDF,

- Technical Assistance Program - ERDF,

- Programs of European Territorial Cooperation - ERDF.

In this paper, support by all the above mentioned programs without Human Capital Program and Programs of European Territorial Cooperation will be assessed.

\section{Research results and discussion}

\section{The types and structure of implemented projects}

Investment priorities assigned to each project were classified into 8 groups. The names of these groups and their components (with numbers indicating priorities) are shown below in the Tab. 1. 
The types of EU co-financed projects according to the investment priorities

\begin{tabular}{|c|c|}
\hline Types of intervention & Investment priorities \\
\hline $\begin{array}{l}\text { Innovations and } \\
\text { entrepreneurship }\end{array}$ & $\begin{array}{l}01 \text { R\&D activities carried out in research centres, } 02 \text { R\&D infrastructure and } \\
\text { specialized centres of technological competence, } 03 \text { Technology transfer, } 04 \\
\text { Support for the development of R\&D, } 05 \text { Advanced support services for } \\
\text { enterprises and groups of enterprises, } 06 \text { Support for SMEs in the promotion of } \\
\text { environmentally friendly products and processes, } 07 \text { Investments in enterprises } \\
\text { directly related to the field of research and innovation, } 08 \text { Other investments in } \\
\text { enterprises, } 09 \text { Other activities to stimulate research, innovation and } \\
\text { entrepreneurship in SMEs }\end{array}$ \\
\hline ICT development & $\begin{array}{l}10 \text { Telecommunications infrastructure (including broadband networks), } 11 \\
\text { Information and communication technologies, } 13 \text { E-services and applications for } \\
\text { citizens, } 14 \text { Services and applications for SMEs, } 15 \text { Other actions to improve } \\
\text { access to ICT for SMEs and their efficient use }\end{array}$ \\
\hline Transport & $\begin{array}{l}16 \text { Railway, } 18 \text { Railway rolling stock, } 20 \text { Highways, } 22 \text { National roads, } 23 \\
\text { Regional / local roads, } 24 \text { Bicycle paths, } 25 \text { Urban transport, } 26 \text { Multimodal } \\
\text { transport, } 28 \text { Intelligent transport systems, } 29 \text { Airports, } 30 \text { Ports, } 31 \text { Inland } \\
\text { waterways (regional and local) }\end{array}$ \\
\hline Energy & $\begin{array}{l}33 \text { Electricity, } 35 \text { Natural gas, } 39 \text { Renewable energy: wind, } 40 \text { Renewable } \\
\text { energy: solar, } 41 \text { Renewable energy: biomass, } 42 \text { Renewable energy: } \\
\text { hydroelectric, geothermal and other, } 43 \text { Energy efficiency, combined production } \\
\text { (cogeneration), energy management }\end{array}$ \\
\hline Environment protection & $\begin{array}{l}44 \text { Municipal and industrial waste management, } 45 \text { Water management and } \\
\text { drinking water supply, } 46 \text { Wastewater treatment, } 47 \text { Air quality, } 48 \text { Integrated } \\
\text { pollution prevention and control system, } 50 \text { Restoration of industrial areas and } \\
\text { reclamation of contaminated land, } 51 \text { Promoting biodiversity and nature } \\
\text { protection (including NATURA 2000), } 52 \text { Promoting clean urban transport, } 53 \\
\text { Prevention of risks, } 54 \text { Other activities for environmental protection and risk } \\
\text { prevention }\end{array}$ \\
\hline $\begin{array}{l}\text { Nature, tourism and } \\
\text { culture }\end{array}$ & $\begin{array}{l}55 \text { Promoting natural values, } 56 \text { Protection and valorisation of the natural } \\
\text { heritage, } 57 \text { Other support for strengthening tourism services, } 58 \text { Protection } \\
\text { and preservation of cultural heritage, } 59 \text { Development of cultural infrastructure, } \\
60 \text { Other support for improving cultural services, } 61 \text { Integrated projects for the } \\
\text { revitalization of urban and rural areas }\end{array}$ \\
\hline Social infrastructure & $\begin{array}{l}75 \text { Infrastructure of the education system, } 76 \text { Health care infrastructure, } 77 \\
\text { Care and education infrastructure, } 78 \text { Housing infrastructure, } 79 \text { Other social } \\
\text { infrastructure }\end{array}$ \\
\hline Other & $\begin{array}{l}73 \text { Actions to increase participation in education and training throughout life, } 80 \\
\text { Promoting partnerships, pacts and initiatives, } 81 \text { strengthening the ability to } \\
\text { implement policies and programs, } 85 \text { Preparation, implementation, monitoring } \\
\text { and control, } 86 \text { Evaluation, research / expertise, information and }\end{array}$ \\
\hline
\end{tabular}

The structure of value of implemented projects co-financed by EU funds in perspective 2007-2013 in different types of areas was presented in Fig. 1. In many cases, the location was not assigned to the projects by beneficiaries (location: not applicable), which makes it difficult to draw conclusions properly. This happened mainly by projects with a broad range of influence like promotion, prevention of digital exclusion through the construction of broadband internet infrastructure, technical infrastructure construction and scientific projects. In other cases containing social infrastructure, nature, tourism and cultural projects and ICT development the location was assigned to most projects. Anyway, the rural areas have had the highest share of funds (above $10 \%$ ) allocated on developing energy infrastructure, social infrastructure; and projects enhancing nature, tourism and cultural development and construction of transport infrastructure (definition and scope of the term transport Infrastructure is described by the EC (2006). Interesting are also proportions between the allocation in urban and rural areas - in most cases much more funds were spent in the cities and towns. The urban areas acquired 5.5 times more on social infrastructure and nature tourism and 
cultural projects and 3 times more on innovations and entrepreneurship and ICT development. This is clearly connected with the polarization - diffusion model of cohesion policy implementation recognizing that it is more important to support the metropolis and stimulate the diffusion of development to the surrounding areas (Wozniak, 2011; Rakowska, 2011). Only shares of funds allocated to transport and energy were similar in both types of areas. The only type of projects where more funds were spent in the rural areas was environment protection ( $9.5 \%$ share in the rural and $6.1 \%$ in the urban areas). The effect of this was a significant development of technical infrastructure in rural areas in Poland (mainly Central and Eastern). In many areas that have been lagging behind in infrastructure so far water systems, wastewater treatment plants and sewage systems were built.

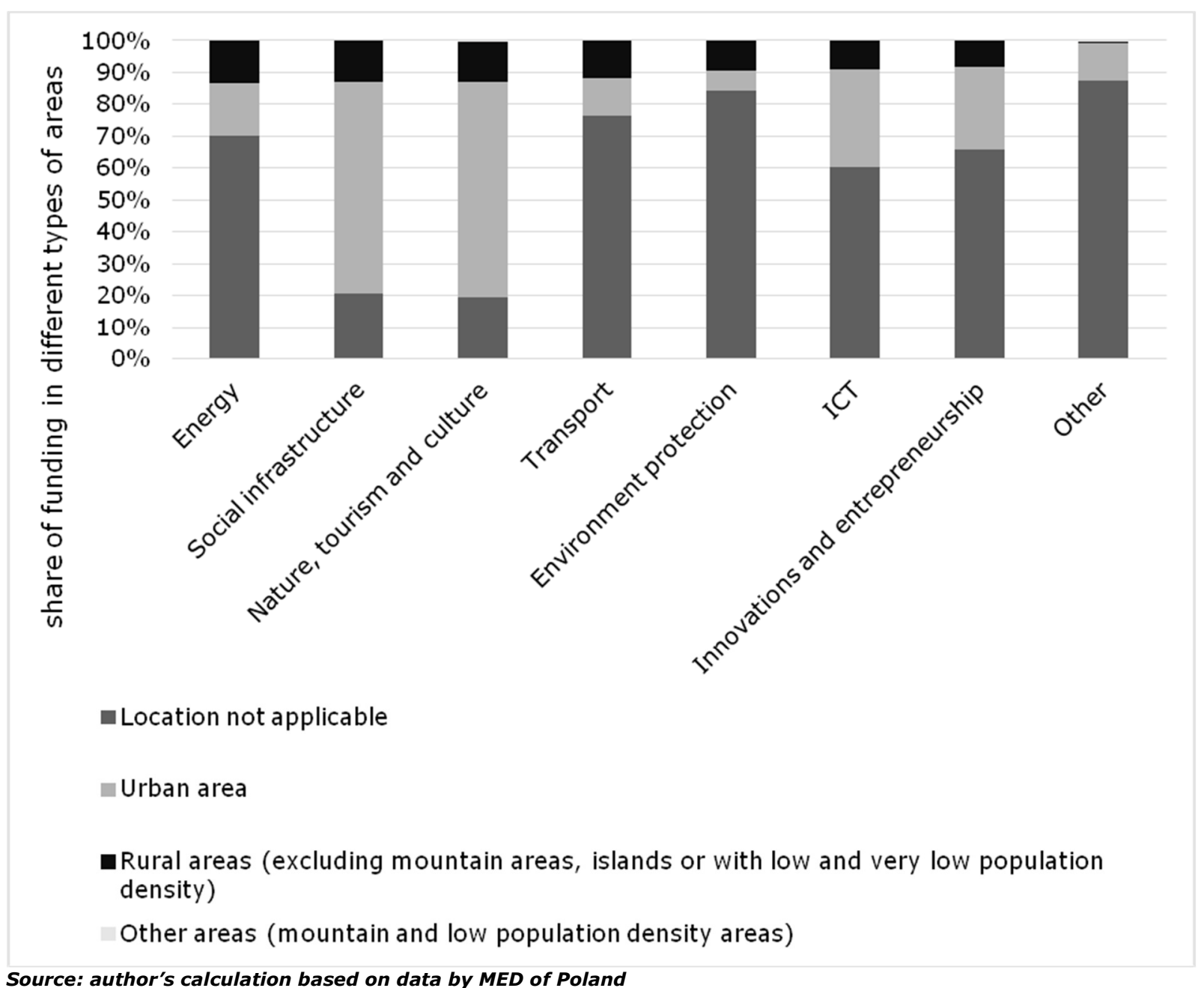

Source: author's calculation based on data by MED of Poland

Fig. 1. The structure of value of implemented projects co-financed by EU funds in perspective 2007-2013 in different types of areas in Poland

\section{Highest share of funding in rural areas - detailed analysis}

The share of projects in the rural areas taking into account detailed classification of investment priorities was shown in Tab. 2. Both the share and total value of projects were presented. As it can be observed, rural areas benefited mostly (the highest share of allocated funds: $>50 \%$ ) from technical and social infrastructure projects as construction of bicycle paths, regional and local roads, enhancing water management systems, also care and education infrastructure. 

The share of rural areas in Poland as beneficiaries of EU co-financed projects
by investment priorities (financial perspective 2007-2013)

\begin{tabular}{|c|c|c|c|}
\hline No & Investment priority (number and name) & $\begin{array}{c}\text { share of } \\
\text { funds in rural } \\
\text { areas } \\
(\%)\end{array}$ & $\begin{array}{c}\text { total } \\
\text { amount of } \\
\text { funding } \\
\text { (m PLN) }\end{array}$ \\
\hline 1 & 24 Bicycle paths & 88.8 & 357.6 \\
\hline 2 & 45 Water management and drinking water supply & 69.3 & 382.1 \\
\hline 3 & 77 Care and education infrastructure & 66.4 & 50.7 \\
\hline 4 & 40 Renewable solar energy & 66.0 & 590.1 \\
\hline 5 & 23 Regional / local roads & 57.8 & 10532.0 \\
\hline 6 & 54 Activities for environmental protection and risk prevention & 55.1 & 117.5 \\
\hline 7 & 42 Renewable energy: hydroelectric, geothermal and other & 46.3 & 58.6 \\
\hline 8 & 55 Promoting natural values & 43.3 & 45.9 \\
\hline 9 & $\begin{array}{l}06 \text { Support for SMEs in the promotion of environmentally friendly } \\
\text { products and processes }\end{array}$ & 38.7 & 88.3 \\
\hline 10 & 56 Protection and valorisation of the natural heritage & 38.4 & 60.6 \\
\hline 11 & 79 Other social infrastructure & 34.1 & 349.2 \\
\hline 12 & 10 Telecommunications infrastructure & 33.0 & 1117.8 \\
\hline 13 & 08 Other investments in enterprises & 33.0 & 2852.0 \\
\hline 14 & 58 Protection and preservation of cultural heritage & 19.3 & 380.2 \\
\hline 15 & 57 Other support for strengthening tourism services & 19.0 & 785.1 \\
\hline 16 & 75 Infrastructure of the education system & 17.1 & 1022.9 \\
\hline 17 & 09 Other activities to stimulate R\&D and entrepreneurship & 15.8 & 412.8 \\
\hline 18 & 46 Wastewater treatment & 15.2 & 2323.8 \\
\hline 19 & 16 Railways & 15.0 & 1047.2 \\
\hline 20 & 29 Airports & 13.0 & 313.0 \\
\hline 21 & $\begin{array}{l}43 \text { Energy efficiency, combined production (cogeneration), energy } \\
\text { management }\end{array}$ & 11.8 & 352.1 \\
\hline 22 & 39 Renewable energy: wind & 11.6 & 169.3 \\
\hline 23 & 53 Prevention of risks (natural hazards) & 10.6 & 486.2 \\
\hline 24 & $\begin{array}{l}51 \text { Promoting biodiversity and nature protection (including NATURA } \\
2000 \text { ) }\end{array}$ & 10.1 & 52.5 \\
\hline 25 & 44 Municipal and industrial waste management & 8.3 & 377.2 \\
\hline
\end{tabular}

Source: author's calculations based on data of Ministry of Economic Development of Poland

More than 1 billion PLN was spent in the rural areas for regional and local roads or railways, telecommunications infrastructure (mainly enhancing internet access, developing broadband networks), infrastructure of the education system (schools and their equipment) or wastewater treatment. Apart from infrastructure more than 2.8 billion PLN was spent on investments in enterprises located in the rural areas, which helped them to increase their competitiveness and develop new activities. Important expenditures have been incurred for activities for environmental protection and risk prevention and promoting natural values. A significant share of funds contributed to support for strengthening tourism services, protection and preservation of cultural heritage and protecting biodiversity and nature protection (including NATURA 2000 areas).

\section{Conclusions, proposals, recommendations}

The paper briefly compared and assessed the structure and value of implemented projects cofinanced by EU funds in perspective 2007-2013 in rural areas in comparison to the urban ones in 
Poland. In general, the structure of allocated funds at the country level was comparable to other Eastern European countries. To assess and analyse the financial expenses of EU funds the investment priorities were classified and the share of projects completed in the rural areas in selected categories was calculated. The main conclusions are stated below.

1) Polish rural areas benefited mostly (the highest share of allocated funds: $>50 \%$ ) from technical infrastructure projects as construction of bicycle paths, regional and local roads, enhancing water management systems.

2) Another important effect was development of social infrastructure as care and education infrastructure.

3) Investments in enterprises located in the rural areas helped them to increase their competitiveness and develop new activities.

4) The urban areas acquired 3-5 times more funds on social infrastructure and nature tourism and cultural projects, innovations and entrepreneurship and ICT development. This is clearly connected with the location of enterprises (mainly in cities) and polarization - diffusion model of cohesion policy in Poland.

5) The only type of projects where more funds were spent in the rural areas was environment protection (which is connected with an enormous development of technical infrastructure).

6) The projects' effects contributed to achieving the following goals of National Cohesion Strategy: Construction and modernization of technical and social infrastructure essential for the growth of Poland's competitiveness (although it has had the higher effect in increasing the life quality), and Increasing the competitiveness and innovativeness of enterprises.

As one can see, the support of EU structural funds for rural areas in Poland was very important, but much smaller than in urban areas. Further studies could be focused on the deepened analysis of the effects of the projects increasing the level of economic development both at country level and in local rural systems.

\section{Bibliography}

1. Bachtler, J., Turok I. (eds.). (2013), The Coherence of EU Regional Policy: Contrasting Perspectives On The Structural Funds. Routledge. London \& New York, p. 441.

2. Commission Regulation (EC) No 851/2006 of 9 June 2006 Specifying The Items to Be Included Under The Various Headings In The Forms Of Accounts Shown In Annex I To Council Regulation (EEC). Retrieved: http://eur-lex.europa.eu/legal-content/EN/TXT/HTML/?uri=CELEX:32006R0851\&from=PL. Access: 18.12.2018.

3. Kowalczyk S. (2007), Fundusze Unii Europejskiej w rozwoju rolnictwa i obszarow wiejskich. (Funds of The European Union In The Development Of Agriculture And Rural Areas). Zagadnienia Ekonomiki Rolnej 2007 No 3, pp. 3-23.

4. Ministry of Economic Development of the Republic Poland, Database of EU-Cofinanced Projects In Poland. Retrieved: http://funduszeeuropejskie.2007-2013.gov.pl Access: 10.11.2018.

5. Pawlicki R., (2014). Strategia Finansowa dla Polski 2014-2020. Fundusze unijne dla przedsiebiorczych. (Financial Strategy for Poland 2014-2020. EU Funds for Enterprising). Difin, p. 254.

6. Polska. Narodowe Strategiczne Ramy Odniesienia 2007-2013 wspierajace wzrost gospodarczy i zatrudnienie. Narodowa Strategia Spojnosci. (National Strategic Reference Framework 2007-2013 Supporting Economic Growth and Employment. National Cohesion Strategy). Dokument zaakceptowany decyzja Komisji Europejskiej zatwierdzajaca pewne elementy Narodowych Strategicznych Ram Odniesienia. Ministerstwo Rozwoju Regionalnego. Warszawa, maj 2007 r.

7. Pondel, H., (2017). Fundusze Unii Europejskiej jako czynnik wspierajacy zrownowazony rozwoj obszarow wiejskich. (Funds of The European Union As A Factor Supporting Sustainable Development Of Rural Areas). Studia Oeconomica Posnaniensia 2017, Vol. 5, No. 5, pp. 88-102.

8. Rakowska J., (2011). Praktyczne znaczenie zastosowania wyrownawczego lub polaryzacyjno-dyfuzyjnego modelu rozwoju regionalnego dla obszarow wiejskich w Polsce po 2013 roku, (The Practical Significance Of Applying A Compensatory Or Polarization-Diffusion Model Of Regional Development For Rural Areas In Poland After 2013). Wies jutra 11/12 (160/161), pp. 26-27. 
9. Satola, L., (2009). Przestrzenne zroznicowanie absorpcji funduszy strukturalnych przeznaczonych na rozwoj pozarolniczej dzialalnosci na obszarach wiejskich. (Spatial Differentiation in The Absorption Of Structural Funds Assigned To Financing The Development Of Non-Agricultural Activities In Rural Areas). Zeszyty Naukowe SGGW w Warszawie seria Problemy rolnictwa swiatowego, t. 7(XXII), pp. 133-142.

10.Schrader, H., (1994). Impact assessment of the EU structural funds to support regional economic development in rural areas of Germany, Journal of Rural Studies. Volume 10, Issue 4, October 1994, pp. 357-365. https://doi.org/10.1016/0743-0167(94)90045-0

11. The Impact of Cohesion Policy 2007-2013 in Poland, Visegrad Group Countries And Partner States, (2017). Ministry of Economic Development, Warsaw, p. 73.

12. Wozniak, J. (2011). Miejsce polskich regionow w systemie rozwoju. (The Place of Polish Regions In The Development System) [at:] Kolczynski, M., Zuber, P. (eds.) Nowy paradygmat rozwoju - najnowsze trendy i perspektywy rozwoju polityki regionalnej. Ministerstwo Rozwoju Regionalnego, Warszawa, pp. 48-57.

13.Zawisza, S., Pachut, T., (2015). Wplyw integracji z Unia Europejska na rozwoj obszarow wiejskich gminy Nowa Wies Wielka. (Influence Of Integration With The European Union On The Development Of Rural Areas In Nowa Wies Wielka Commune). Roczniki Naukowe SERiA tom XVII zeszyt 5, pp. 361-366. 